\title{
Progrese Heport
}

by

Iom Sth University of Solence and Tochnology

Ames, Iows

Februsry 1, 1972-July 31, 1979

PRFA ARHD FOR THE U.B. ATONIC BHERGY CONISSIOA

INDFR COATRACT AT (11-1)-1680

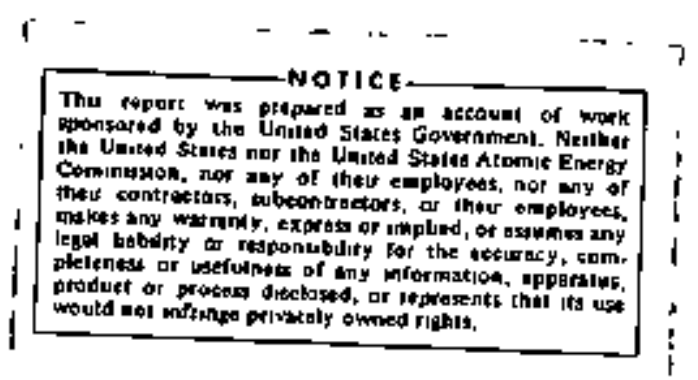




\section{DISCLAIMER}

This report was prepared as an account of work sponsored by an agency of the United States Government. Neither the United States Government nor any agency Thereot, nor any of their employees, makes any warranty, express or implied, or assumes any legal liability or responsibility for the accuracy, completeness, or usefulness of any information, apparatus, product, or process disclosed, or represents that its use would not infringe privately owned rights. Reference herein to any specific commercial product, process, or service by trade name, trademark, manufacturer, or otherwise does not necessarily constitute or imply its endorsement, recommendation, or favoring by the United States Government or any agency thereof. The views and opinions of authors expressed herein do not necessarlly state or reflect those of the United States Government or any agency thereof. 


\section{DISCLAIMER}

Portions of this document may be illegible in electronic image products. Images are produced from the best available original document. 
ABSTRACF

A zasis for studying indigenoug interlayer co sxchango was astablishod by surveyIng the Ca content of nieag and nodsfying the exchang procedures. Varions size-fractions of lepidolite were then degraded and the percentage $\mathrm{Cs}$, Fb and $K$ exchanged in specifled parlods were shom to be the sane. Horeover, the Cs exchange data refleoted the effects of prtic]e aize already egtablished with $K$. An exchange of $\mathrm{Cs}$ for $\mathrm{Ha}$ in degraded unploe of the same lepidolite size-fraotions wo carried out and the exchangesbllity of this addod Cs was determined. Kajor differencel in the exchange data for indigenous and added $C_{t}$, dried or hoa ted oamples, and lepidolite or lepidonelane fractions more oberved.

Detalled studies of the changes in interlayer $K$ exchangesbility that are Induced by preher ting ccara-grained muscovite at different temperatures and for different. periods established a clase relationship between the rate of $\mathrm{X}$ exchange and the welght lost by dehydroxylation. Additions of $\mathrm{H}_{2} \mathrm{O}_{2}$ to solutions enployed in the exchange of $\mathrm{Ha}$ for interlayer eations in lepidoalane produced a maj increase in the rate of exchange that could not bolated to Fe oxidation in the nies core or exfollation by ovolved axygen.

\section{DETH ILED REPORT}

A aubstantive summary of the activitied and acconplishnents of the past thres yeara of this project has ben prepured this yoar (Docunent c00-1680-19). Thus, a detalled account of our progress for the pest year would be unduly repetitive. A brief statement identifying the contributions fron just the one year will bo presented instead.

1. Indigenous Cst A survey of the Cs content of ava1jable nica samples was continued but falled to Froduce a mineral with more interlayer Cs and Rb than the lepidolite selected initially for a study of interlayer Gs exchange. A sanple of this lepidolite was dry ground in a Shatterbox and geveral size fractions were separated and characterized in terms of total and NaTPB-extractable Cs, Rb and K. To do so, further wock on wothods of analyzing solutions of the three cations, and techniques for srall anounts of exchange had to be carrlod out. Some of the ccerge gize-fractions are atill undergoing treatient becausw this mineral releages its interlayer oftions very slorly. However, the exchange data for 2-5p and $<0.2 \mu$ fractions show the distribution of Ca, ib and $K$ in the perticles and the exchangeability of these catcons are essentially the same.

2. Added Gg: Having used lapidamelane and nuscovite samples in an exploration of ways of sorbing interlayer $\mathrm{Cs}$, a shift has wade to lepidolits size-fractions once K-depleted samples becano avallablo. This mo dose to obtain a conparison of interlayer and added Cs exchange in the same canple. By terminating the HaTPE-degraintion of the lepidalite with bolling 1E EsGl, a sanple with 140 ne Cs $/ 100 \mathrm{~g}$ rag obtained. Portions of this ls-degraded lepidolite were a 1 r dried or cven dried for 24 hours at $110^{\circ} \mathrm{C}$ or $450^{\circ} \mathrm{C}$. Heating the sarple at $110^{\circ} \mathrm{C}$ had little effect in the subseglent exchange of $\mathrm{Ca}$ by la, but the $450^{\circ} \mathrm{C}$ treatment reduced the Inte of exehange. Ag with $K$, added 1nterlayer Cs wa easier to ceplace than Indigenous Cs. The role of other cations in the Inter]ayers and the wethod of adding the Ce rentins to be detarmined.

3. Heated micaceous ainerzist The use of heat trentments to induce changed in interlayer $\mathbb{K}$ exchange was continued with a varlety of ground and naturally fine- 
grained winerals. With this appcoch, general relationships between $K$ exchangeabllity and other mineml characteriaties were estabilshed. At the osme time, detalled atudies of the effects of hest trestments on muscovite (diactahodral). phlogopite (Jon Pa, trioctahedral) and lepidonelano (high Fe, triootahodrel) eaples were initiated. By using weight loss as oridenoe of dehydroxylation in heated samples, a close asscetation between the $\mathrm{K}$ exchangesility and hydroxyl status of auscovite wro establiahea. Phlogopite was not debydroxylated and not altered in terus of $\mathbf{x}$ exchengeabij.ity by tenperatures up to $800^{\circ} \mathrm{C}$. The lopidonelane eaples, however, exhibited a ma jor feduction in rate of $\mathrm{K}$ exchange whan they were deprotonated by hest induced Fe oxidation. Frytallographic changet in heated arples of these three micas have been deternined and rela ted to the incidence of weight loss, Fe oxidation and vartations in interlayer 16 exchengeabil.1ty.

4. Redox conditionsi While the 11terature continues to enphasize the poss1bility of altering the exchangesbility of interlayer catione by ohanging the redox status of the structurs 1 fo In nlace ous ninersls, this project hes veritied that $F_{6}+$ oxidgtion in contracted ainorals dpes not occur when $\mathrm{H}_{2} \mathrm{O}_{2}$ ia added to the solution. Instead, win find only the Fefl in the weathered poriphery of prrtisles 1a oxddized and the rate of $\mathrm{K}$ exchange is incrested, not decreased, by the presence of $\mathrm{H}_{2} \mathrm{O}_{2}$. Th1s obaervation has been tudied in some detall during the pest year. Conparisong of alnerals of th different $\mathrm{Pe}^{++}$content suggest the

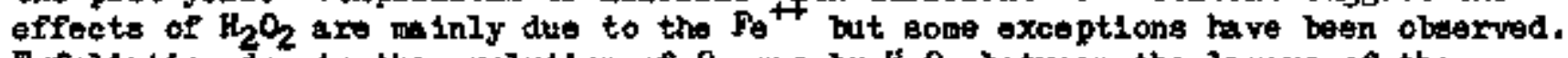
Exfollation due to the ovolution of $\mathrm{O}_{2}$ as by $\mathrm{F}_{2} \mathrm{O}_{2}$ between the layers of the wo thered edges of the minerale has also been ruled out as an explanation for the 1nereased rate of $K$ exchange. Instead, the rate of edge westhering by diffusfon Is entanced by the presence of $\mathrm{H}_{2} \mathrm{O}_{2}$ in the solution. Ingtability of the TPB ion in $\mathrm{H}_{2} \mathrm{O}_{2}$ solutions bas conplice ted this investigation.

5. Procedures! Host of the interiayer oation exchenge experiments encountered in this project involve enough of the cation to circunvent analytical problens. When the saple size is very soall (as in finersl/solution experinents) or does not conta in wuch of the ostion under question (e.g. Indigenous $\mathrm{Cs}_{8}$ or reverted $\mathrm{E}$ In Cs desogded ninerala) som noilfication in the experisental procedure is encential. Yarious wys of aldinizing the finsl volune of the solution with the replaced eation tut at1ll provide a complete removel of TPB and ninersl have been exartned this year. Considerable success has been achleved with a procedure Involving the renoval of excess TPB by flltrstion and the ves of cu Instegd of $\mathrm{Hg}$ for the deconposition of the realning TPB. Other procedures uder study this year tave been those providing controlled lavels of Gs addition to interlays surfaces of micactous insrals.

\section{POREIGH TRA VEL}

A pper on results fron th1s project was prosented at the 1972 Internat1onal Glay Conference, Hadr1a, Spin. Further detalle regarding the purpose and accompliahments of this trip are deseribed in Fore 445 and the trip report subnitted on Auguat 4, 1972 .

\section{FURLIQATIOHS}

600-1680-14: Extreteble potasslum in Grundite 1ll1te: II. Effects of perticlesizo and grinding. S.J. Saith and A. D. Seott. Soll Sc1. in press (1973).

c00-1680-151 Chenges in interlayer potassium exchangoob2]1ty induced by heating 
3

alcas. A. D. Scott, P. T. Isn 11, and R. R, Lootis. Proc. Int. Clay Conf. Hadrid, in preas (1973).

CO0-1680-17; Bxchangeab1lity of potasaiun in hested f1ne-grained nlescoous minexas. S, J, Silth and A. D. Soott. Clays and Clay Minersis, Subnitted for publication (1973).

TIHT G PROJPET

A, D. Scott, Princ1pal Investigator.

Pebruary 1, $1972 \ldots$ April 30, $1973 \ldots \ldots$. . . . . . . .

Hay 1, 1973 - July $31,1973 \ldots \ldots \ldots$. . . . . . . . $30 \%$ ant1c1pat

PRERARED BY

$\frac{A \cdot D \cdot S \cdot S A_{2}}{A \cdot D_{1} \operatorname{sctt}}$

!

7 